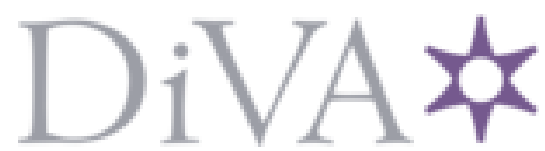

http://www.diva-portal.org

\title{
Preprint
}

This is the submitted version of a paper published in Security Dialogue.

Citation for the original published paper (version of record):

Lundborg, T. (2016)

The Virtualization of Security: Philosophies of Capture and Resistance in Baudrillard, Agamben and Deleuze.

Security Dialogue, 47(3): 255-270

https://doi.org/10.1177/0967010615625474

Access to the published version may require subscription.

N.B. When citing this work, cite the original published paper.

Permanent link to this version:

http://urn.kb.se/resolve?urn=urn:nbn:se:fhs:diva-6480 


\title{
The Virtualization of Security:
}

\section{Philosophies of Capture and Resistance in Baudrillard, Agamben and Deleuze}

\author{
Tom Lundborg
}

Security Dialogue, First View, February 2016

\begin{abstract}
The virtual has during the last couple of decades emerged as a forceful conceptual tool in security studies. While used primarily in order to question assumptions about an objective truth concerning the meaning and value of security and different forms of insecurity, the implications of drawing on this concept vary considerably depending on how the virtual is conceptualized, and specifically how the potentiality of the virtual is linked to the process of actualization. Turning to the philosophies of Baudrillard, Agamben and Deleuze, as well as key thinkers in contemporary security studies, this article delineates three different approaches to analysing the virtualization of security. Focusing in particular on how these approaches point to contending views of 'capture' and 'resistance', it is argued that the choice of approach has serious implications for grasping what is at stake politically in the process of virtualization. These implications relate, more precisely, to how the virtual opens up and/or closes down the spaces of resistance that the modern subject of security traditionally has relied upon. In this way, the virtualization of security is not only important for thinking about capture and resistance, but challenges the very ground on which the modern subject of security rests.
\end{abstract}

\section{Introduction}

During the last couple of decades numerous debates have taken place between positivist and post-positivist approaches to security and International Relations (IR) (see, for example, Lapid, 1989; Booth et al., 1996; Dunne et al., 2013). Contending views of reality and their different implications for analysing security - what it refers to, who it is 
for, and how it relates to threats, dangers and insecurity - have been at the forefront of these debates. If there is a key delineation cutting through these debates it is the one between those who argue that security should be studied with reference to an independently existing realm that can be accessed, known and represented as such or in itself (e.g. Walt, 1991; Mearsheimer, 1995), and those who claim that security lacks an external signified and must rather be linked to discursive and representational practices (e.g. Campbell, 1998; Hansen, 2006).

While positivist and post-positivist approaches to security seem to clash fundamentally over how to grasp the reality of security they also share a certain commitment to studying what may be referred to as an 'actualized' reality. Whether this reality pertains to an independently existing realm that can be known as such and in itself or a realm produced by images, texts and other representational practices, it is, nevertheless, a form of reality that for various reasons has come to be accepted as such. According to positivists and (most) post-positivists alike, this is consequently the reality that security studies should engage with.

In this article I turn to the concept of the 'virtual' in order to explore other ways of thinking about the relation between security and reality, which go beyond the positivist/post-positivist divide. To be sure, this concept is not new to security studies but has already been used in some very prominent analyses. For example, James Der Derian has demonstrated how the virtual can be used for analysing the impact of new technologies of information and the use of simulation in warfare and military training (Der Derian, 1990, 1993, 2001). François Debrix has explored how the UN can be analysed as a 'virtual agent' whose primary aim is to mobilize by means of simulation the 'appearance of collective security' (Debrix, 1999: 9). Mick Dillon has shown how the rise of digital and molecular sciences has led to the creation of a 'virtual politics of security', which transforms the virtual potential of bodies into the constant risk of becoming-dangerous (Dillon, 2003). And Nick Vaughan-Williams has pointed to how the UK's new border security doctrine can be linked to a process of virtualization that locates the 'border' in a variety of offshore and domestic spaces; a process that simulates 'the effect of total security' (Vaughan-Williams, 2010: 1082). In a very broad 
sense, the virtual in these analyses highlights something taking place beyond the realm of representation and the actualized layer of reality; something that belongs, rather, to a virtual dimension of reality.

Adding the virtual to the study of security raises a series of important questions. One of these questions, which this article aims to address, is how to analyse what is at stake politically in the virtualization of security. Rather than seeking to arrive at one definitive answer to this question, the article considers three possible approaches to analysing the virtualization of security. Drawing on Jean Baudrillard, Giorgio Agamben and Gilles Deleuze, these approaches are referred to as: (i) the virtual as a new reality; (ii) the virtual as a potential reality; and (iii) the reality of the virtual. The main reason for choosing these thinkers is that they already play a prominent role in the security studies literature, especially in the literature on security and the virtual. At the same time, there is a tendency in this literature to combine these thinkers in ways that are far from clear and which often end up, wittingly or unwittingly, prioritising one particular concept of the virtual.

In this article I argue that choosing one concept of the virtual over another has serious implications, not least for addressing the question of what is at stake politically in the virtualization of security. This question relates, more precisely, to how the process of virtualization opens up and/or closes down the possibility of resistance and political contestation. Following David Couzens Hoy, resistance requires a certain sense of 'freedom', which is 'tied conceptually to the openness to possibility' (Hoy, 2005: 234). Without this openness, resistance becomes impossible. In security studies the issue of resistance is closely linked to the question of whose security is at stake, that is, the 'subject of security' (see Walker, 1997). In modernity the primary subjects of security are usually said to be the sovereign territorial state and/or the sovereign individual. As 'moderns', we assume that these subjects have the capacity to represent their surroundings and, if necessary, change them. Even if the possibility of change is ultimately conditioned by certain limits, set for example by the international state system, the very idea of representing and refiguring reality reflects a series of assumptions that are distinctively 'modern'; assumptions, for example, of sovereignty, 
freedom, autonomy, democracy, enlightenment and identity (see Edkins et al., 1999; Williams, 2001; Colebrook, 2005). Against this background, the political stakes of virtualization are high, indeed, as this process poses a fundamental challenge to many of the most basic assumptions on which the modern political subject and the modern subject of security rest.

This article's main contribution, thus, is that it shows what happens to the subject of security once we move from an actual to a virtual layer of reality. Specifically, it shows how this movement affects the capacity of the modern subject to resist whatever happens to 'it' within the realm of the virtual. Do resistance, sovereignty and the openness to possibility disappear along with actualization and representation, or do they still have an important political role to play? If the answer to the latter question is yes, then how should we grasp the relationship and tensions that emerge between actualization and virtualization? The underlying assumption of this article is that any attempt to address these questions must begin with a thorough examination of the concept of the virtual.

The article begins by considering Baudrillard's concept of the virtual, which points to the emergence of a new virtual security order, based on techniques and technologies of simulating a sense of 'total' or 'complete' security. The second section focuses on Agamben's analysis of the links between biopolitics and the contingent production of bare life as a virtual potential, which may or may not be actualized through the sovereign ban. In the third section I turn to Deleuze's concept of the virtual as something that is real only insofar as it remains a pure potentiality; as soon as we move from potentiality towards actuality the reality of the virtual is therefore lost according to Deleuze. In the final section, these three approaches are brought together and the differences and similarities between them are discussed and analysed, with special emphasis on the issues of capture and resistance.

Before we begin it is important to stress that like all readings, the ones offered here rely on particular interpretations. Admittedly, the article traverses vast philosophical grounds. Due to the limited space of this article I am not able to cover all existing and other potential interpretations. At the same time, it is also important to emphasise that 
my aim when turning to Baudrillard, Agamben and Deleuze is very specific, namely to examine how their respective concepts of the virtual can be used for analysing what is at stake politically in the virtualization of security. It is consequently on the basis of this particular aim that we shall now proceed to investigate their ideas.

\section{Baudrillard: The virtual as a new reality}

Whereas we could face up to the unreality of the world as spectacle, we are defenceless before the extreme reality of this world, before this virtual perfection. We are, in fact, beyond all disalienation. This is the new form of terror, by comparison with which the horrors of alienation were very small beer. (Baudrillard, 1996: 29)

Jean Baudrillard's concept of virtual is by far the most influential in security studies among those examined in this article. It has played a particularly important role in attempts to grasp the emergence of new forms of simulation used, for example, in contemporary warfare, military training and biometric security technologies. Here, the virtual marks the beginning of a completely new reality, which differs from older conceptions of what is real. Instead of an actual reality, the proliferation of electronic and digital media, screens and computers means that reality has become increasingly virtualized. For example, we rely more and more on memories that are stored on memory sticks and computers, making memory something 'virtual'; we interact with people on the Internet without ever having to meet them in person, creating 'virtual communities'; and computer games and simulations are developed in order to create new 'virtual worlds'. The role and significance of the virtual in this context are sometimes considered to be limited to a dimension of life that exists side by side with other (and older) conceptions of what is real. But sometimes, as in the case of Baudrillard, the virtual, in its various manifestations, has given us a completely new sense of reality: a 'virtual reality'. Reality in this sense no longer has any 
correspondence to an actual world of representation and exists solely at the level of 'simulation' and 'simulacrum'. Baudrillard notes: 'Whereas representation tries to absorb simulation by interpreting it as false representation, simulation envelops the whole edifice of representation as itself a simulacrum' (Baudrillard, 1983: 11).

For Baudrillard, there can be no sustainable distinction between the actual and the virtual. The actual has been absorbed by simulation, making reality something that only exists virtually. The distance between the virtual and the actual has collapsed and all that remains is a void or a desert of the real in which there is nothing left to represent, mirror or actualize. He argues:

In the past, the virtual had the possibility of becoming actual [réel]. Actuality was even its destination. There was, then, possibility. Today, when the virtual is winning out over the real, there's no longer any possibility, since everything is immediately realized. ... The result is acceleration into the void ... the desert, as I put it. (Baudrillard and Noailles, 2007: 78)

In the desert of the real, where copies of copies have replaced the relationship between the copy and the model, there is an abundance of codes and algorithms, which cannot be tied to a clear source or origin. Computer surveillance or 'dataveillance' demonstrates how this abundance of information has completely reshaped the contemporary landscape of global security. In this virtual security order, the subjects of security are no longer in control of the information that is supposed to protect them from dangers and threats. The information is rather in control of them, highlighting a 'paradoxical game of subject-object inversion that means just one simple thing: we believe we think the world, but the belief is mutual. It's a dual relation, and we can think it only because it thinks us in return' (Baudrillard and Noailles, 2007: 103; see also Bogard, 1996: 27).

The excessive production of new dangers that characterizes the contemporary social and political order in the West (see Huysmans, 2014) can be seen as the logical outcome of a system that gradually has taken charge of our perception of reality. In the enormous amount of data constantly being produced there is an excess of dangers to be dealt with 
- an excess that corresponds directly to the emergence of a new virtual reality, in which the modern subject of security gradually disappears (Baudrillard, 2002: 18). This new reality makes it increasingly hard to satisfy the desire for more security. The bigger the 'machine' becomes the more reason to worry that something will go wrong; something that eludes established systems of sovereign control and mastery, causing them to collapse from within, 'implode' rather than 'explode'. This vicious circle of increased security/insecurity takes us further and further away from the old sovereign subject who sought to represent threats and dangers as they gradually appeared and became actualized. In the new virtual security order there is no time for representation or actualization. The immediacy of the flows of information means that all threats are immediately realized, in 'the time of virtual reality' and through 'simultaneous screens and networks' - without going through the detour of actualization (Baudrillard and Noailles, 2007: 119). Within this order we are thus forced encounter a new reality principle, the main purpose of which is to exterminate all forms of contingency without any delay. The only thing that is considered worthy of being aspired towards is a sense of 'total' or 'complete' security, which will eradicate any traces of 'evil' that might harm the simulation of the maximum good. According to Baudrillard:

You've only to take the 'zero deaths' formula, a basic concept of the security order. It's clear that this equates mathematically to 'zero lives'. By warding off death at all costs ... we're being turned, through security, into living dead. On the pretext of immortality, we're moving towards slow extermination. It's the destiny of maximum good, of absolute happiness, to lead to a zero outcome. ... This is how things are getting better and better and, at the same time, worse and worse. (Baudrillard and Noailles, 2007: 33-34)

That things are getting both better and better and at the same time worse and worse is one of the great paradoxes of the search for total security and the maximum good. It is a paradox that springs from a virtual reality in which everything is simulated and nothing represented or signified. Within this reality, security does not 'signify' anything, be it the state, the human individual, the environment or the economy. Security and 
insecurity are not independent signifiers awaiting an external signified. They are part of the same virtual reality, the same simulations, and the same machine, which has lost the potential for any form of transcendence. There is no external reality to be transcended by a sovereign subject; no actual objects of security/insecurity to be grasped through representation and signification. Trying to cling on to the idea that there is indeed an 'actual' reality of security/insecurity can only be said to conceal the fact 'that reality no more exists outside than inside the limits of the artificial perimeter' (Baudrillard, 1994: 14).

The gradual disappearance of the modern subject of security is also explored in Der Derian's pioneering work on the virtualization of security. Der Derian uses the virtual to examine, among other things, new technologies of information and the use of simulation in warfare and military training (see, for example, Der Derian, 1990, 1993, 2000, 2001). Unlike earlier technological developments, which primarily sought to change the 'means of transportation, communication and information', Der Derian notes how 'virtual innovation is driven more by software than hardware, and enabled by networks rather than agents, which means adaptation (and mutation) is not only easier, but much more rapid' (Der Derian, 2000: 771). 'Time', he argues, thus 'displaces space as the more significant strategic "field" (Der Derian, 1992: 134).

Real-time simulations and the speed of contemporary warfare are the true hallmarks of the virtualization of security and war. Together they contribute to the erosion of 'war' as the 'ultimate reality-check of international politics' (Der Derian, 2000: 775). A similar point can be made about 'sovereignty', which, instead of merely referring to the exercise of power over a clearly demarcated territory, relies ever more heavily on the use of new media to produce images of threats and dangers (Der Derian, 2000: 775). Cynthia Weber (1995) pushes this point even further when arguing that sovereignty, far from being territorially fixed and possible to declare as either present or absent, has become simulated. To be sovereign, she notes, the 'state' must 'control the simulation of its "source" of sovereign authority and simulate a boundary ... which marks the range of its legitimate powers and competencies' (Weber, 1995: 129). In this way, sovereignty lies beyond representation; it lacks reference to an external reality and 
belongs, rather, to a simulated reality. Neither true nor false, neither real nor imaginary, this new reality has no definite boundaries and can incorporate anything.

The simulation of sovereignty underlines, once again, the gradual disappearance of the modern subject of security and shows specifically how the subject's authority and capacity to represent an outside world have been disrupted. Yet another example of this process can be found in Debrix's analysis of the UN as a 'virtual agent' that simulates the 'appearance of collective security in a world that still looks disorderly' (Debrix, 1999: 9). The simulated reality produced by this virtual agent consists, for example, of visual constructions of UN peacekeeping that help create 'a fantasy space or dream land of international affairs (where peacekeeping operations are successful, governance is realized, etc.)' (Debrix, 1999: 216). Along similar lines, Vaughan-Williams (2010: 1080) points to how new border security technologies simulate the effect of total security. He finds an excellent example of this process at work in the UK's new border security doctrine, in which the traditional idea of protecting a fixed territorial space is significantly altered by a continuиm of security practices. In relation to this continuum, the UK's 'border' does not simply refer to the outer edges of the state but can be found in offshore spaces where people are prevented from boarding planes and trains; in biometric technologies that are used to determine the identity of people trying to enter the country; and in attempts to preempt terrorist attacks throughout society. The territorial borders of the sovereign state are clearly disrupted in this process and to a considerable extent replaced by a new virtual space of existence.

\section{Agamben: The virtual as a potential reality}

If today there is no longer any one clear figure of the sacred man, it is perhaps because we are all virtually homines sacri. (Agamben, 1998: 115)

While Baudrillard encourages us to think of the virtual as a new reality, which has left the 'old' reality principle based on actualization, Giorgio Agamben seeks to maintain a tension between the virtual and the actual. Drawing on the Aristotelian notion of a pure 
potentiality, the significance of the virtual in Agamben's work is tied to the idea of a dynamic force that enables something to become actualized. Crucially, this force is not generic in the sense of applying to everyone in the same way. Nor does it exist externally to that which has the potential to be actualized. Rather, potentiality is here referring to a vital force that is immanent to that which has the potential to be actualized, which means that it is "not simply the potential to do this or that thing but potential to not-do, potential not to pass into actuality' (Agamben, 1999: 180). This force is vital, moreover, because nothing can ever remain actualized without it. As soon as the potential to do and to not-do disappears, the process of actualization has lost its necessary and underlying force. According to Agamben (1999: 184): 'Contrary to the traditional idea of potentiality that is annulled in actuality, here we are confronted with a potentiality that conserves itself and saves itself in actuality. Here potentiality, so to speak, survives actuality and, in this way, gives itself to itself' (emphasis in orginal). A straightforward dichotomy of potentiality/reality is thus avoided. There is an element of reality embedded in the Aristotelian notion of potentiality since nothing can ever be actual or real without it.

While Agamben's notion of potentiality as a vital and immanent force is based on his reading of Aristotelian philosophy he also uses it as a crucial ingredient in the development of his own philosophy and especially in his work on biopolitics. In Homo Sacer, Agamben puts forward his controversial thesis on sovereign power and bare life by stating that in the current order we are all 'virtually homines sacri' (Agamben, 1998: 115). Homo sacer or 'bare life' refers to a life that may be killed yet not sacrificed (Agamben, 1998: 8). It lies at the very heart of the Western political paradigm, providing the latter with its original biopolitical structure, which has existed since antiquity and intensified during modernity. For Agamben, the structure of the Western political realm is 'biopolitical' since it relies on the constant potentiality of sovereign power to ban the politically qualified life of citizens (bios), and reduce life to a 'simple natural life' or the 'simple fact of living' (zōē). Homo sacer or bare life is a life that exists in a zone of indistinction between bios and zoe (Agamben, 1998: 181). It highlights the production of a biopolitical body, which can never be sure on which side it belongs: the side of bios or zoē (Agamben, 1998: 6). Accordingly, this body also 
constitutes an always potential target of sovereign power, which has the authority to decide if a life is deemed worthy of being politically qualified or if it should be reduced to the simple fact of living and therefore also of dying.

As Vaughan-Williams (2010) has pointed out, Agamben's thesis on biopolitics is commonly misinterpreted as an exaggerated claim about a generalized state of exception in which the exception has become a permanent rule. Such an interpretation tends to miss the important role that the concept of the virtual plays in Agamben's statement that we are all 'virtually homines sacri'. In emphasising the 'virtual', Vaughan-Williams argues (2010: 1079), it is possible to arrive at a more nuanced reading of Agamben's thesis, which avoids the notion of a generalized state of exception. One way of analysing the significance of the virtual in this context is to return to Agamben's reading of potentiality in Aristotelian thought. To say that we are all 'virtually homines sacri' can then be taken to mean that as members of Western political communities we are all marked by the potentiality to be excluded from the politically qualified life and reduced to the simple fact of living and dying. For Agamben, this potentiality is a necessary precondition for existing within the Western political paradigm; a precondition of our ontological existence within a political order based on the workings of sovereign power and specifically the logic of the sovereign ban. The potentiality of being excluded can, in this sense, also be seen as a vital force, without which sovereign power would have nothing to actualize by means of the exception. In order for sovereign power to 'work', the potentiality of the ban is just as important as the actualization of the ban, and it is precisely where this potentiality and actuality meet that sovereign power finds its home. 'At the limit', writes Agamben, 'pure potentiality and pure actuality are indistinguishable, and the sovereign is precisely this zone of indistinction' (Agamben, 1998: 47).

For Agamben, the potentiality of being excluded through the ban constitutes an integral part of modern political subjectivity. He thus argues that 'only if it is possible to think the relation between potentiality and actuality differently - and even to think beyond this relation - will it be possible to think a constituting power wholly released from the sovereign ban' (1998: 44). The reason why it is so hard to think of potentiality outside 
its relation to actuality is that potentiality and actuality have entered a zone of indistinction within the limits of the same (biopolitical) paradigm. Potentiality is thus locked into a particular, violent relationship with actuality. Potentiality, in this particular context, is not just any potentiality but the potentiality to disappear, to be tortured, excluded and killed. It is the potentiality to be excluded from the norm by means of the exception. It is a potentiality, moreover, that is necessary in order to make 'life' into an object of security. Since every subject has the potential to be excluded through the ban, anyone can also be treated as a potential threat or danger, a potential becomingdangerous that must be responded to in the name of security.

Dillon (2003) makes a significant contribution to a deeper understanding of the ontological theme of becoming, which informs Agamben's biopolitical paradigm. Dillon points to how, in the context of modern biopolitics and the rise of digital and molecular sciences, what matters most is the virtual potential of bodies, specifically the potential of becoming-dangerous. The ultimate goal of biopolitical forms of control is to preempt this potential; that is, to act directly on it before and irrespective of its actualization. Thus, rather than responding to the actual being of bodies, security requires the command of the future becoming of bodies. Security is, in this sense, transformed into a 'boundless science', which targets bodies-in-formation and seeks 'anticipate their disposition to pathology' (Dillon, 2003: 538).

In order to study the ever intensifying interaction between digital/molecular sciences and bodies-in-formation, Dillon makes a key analytical distinction between the 'technovirtual' and the 'onto-virtual'. While the former refers to new technologies of information and simulation (à la Baudrillard), the latter refers to an open and unpredictable process of becoming. While analytically distinguishable, however, the techno-virtual and the onto-virtual constantly flow into one another. Technology thus conditions a particular form of becoming, while ontology is no longer able to exist in a 'pure' sense, independently of the technologies with which it interacts. As Dillon (2003: 552) puts it: 'The virtualisation of security in the age of digitalisation is therefore very much an onto-political as it is a military-technical development'. 
The nexus of the onto/techno-virtual is frightening, to say the least, as it captures the enigma and unpredictable becoming of life within a biopolitical form of control that targets the potentiality of becoming and bodies-in-formation. Life thus becomes part of a violent politics of response, which closes down the potentiality of becoming by preempting the future. However, as we shall see in the final section, Agamben also develops ideas about how this relationship between potentiality and actuality breaks down and is rendered 'inoperative'. He does so by exploring the other side of potentiality: the potential to not-do, also to be found in the work of Aristotle, and uses it to highlight a disruptive as well as creative force that refuses to operate according to dominant forms of actualization within the limits of the biopolitical paradigm.

\section{Deleuze: The reality of the virtual}

The virtual is fully real in so far as it is virtual. (Deleuze, 2004a: 260)

If, at the limits of Agamben's biopolitical paradigm there is a zone of indistinction in which the potentiality of the virtual is inseparable from the moment of its actualization, at the limits of Deleuze's philosophy we find a clearer distinction between virtuality and actuality (see, especially, Deleuze, 2004a, 2004b). This distinction is crucial for Deleuze because it enables him to conceptualize the virtual as something that is real only insofar as it is not reduced to the moment of its actualization. Thus, while Deleuze's concept of the virtual is similar to the Aristotelian notion of a pure potentiality, which may or may not be actualized, the reality of the virtual is for Deleuze not dependent on its actualization. Nor does it relate to a 'new' reality, which is simulated with the help of computers, screens and algorithms. For Deleuze, the virtual is very much real in itself. It is, as Brian Massumi puts it, something 'real-but-abstract', which means that it never pre-exists and cannot be mediated. It is 'never present in position, only ever in passing' (Massumi, 2002: 5). The virtual, in this sense, highlights something paradoxical that eludes attempts to be made sense of, captured or represented in any straightforward way. 
When thinking of the virtual as something that eludes the actualized 'being' of subjects and objects, we move away from the zone of indistinction that informs Agamben's biopolitical paradigm and especially his notion of bare life: a life defined by the potentiality to be excluded through the sovereign ban. In Deleuze's philosophy, the potentiality of the virtual is rather the condition of becoming itself; a condition that destabilizes any attempt to capture becoming within one and the same form of 'being'. As Steven Shaviro (2007: 4) puts it, potentialities or potentials 'can energize or "inform" a subject, but they do not determine its nature ahead of time. There is no resemblance, and hence no preformation. The subject cannot be given in advance; it must always emerge anew, in an unforeseeable way...' Thus, despite endless attempts to act directly and violently on the becoming of the subject, the potentiality of becoming always exceeds the inscription of actualized forms of being. Another way to think of this excess of becoming can be found in Deleuze's book The Logic of Sense, which revolves around the notion of a 'double structure' of the event. By this he means that the event always consists of two different sides: one virtual and one actual. On the side of the virtual, Deleuze (2004b: 172) writes, 'there is the future and the past of the event considered in itself, sidestepping each present, being free of the limitations of a state of affairs, impersonal and pre-individual, neutral, neither general nor particular'. Singularity, virtuality and the pure event all belong to an abstract-yet-real ontology based on multiplicity and an unpredictable movement of becoming. Crucially, the reality of this ontology cannot be reduced to the ways in which it is actualized through, for example, attempts to capture the becoming of the subject as a particular form of being. As soon as we move from becoming to being, or from immanence to transcendence, the reality of the virtual is inevitably sacrificed or lost; it is lost in all the illusions produced by attempts to represent something that ultimately eludes representation (Deleuze, 2004a: 264).

While for Deleuze the reality of the virtual depends upon a clearer distinction between the virtual and the actual, much of Deleuze's philosophy, including his work with Félix Guattari, seeks to theorize the interaction between the virtual and the actual (see, especially, Deleuze and Guattari, 1994). The most significant concepts in the Deleuzian vocabulary are, in this sense, actualization and counter-actualization. While the former 
signals a movement from the virtual to the actual, the latter points in the reverse direction: from an actualized state of affairs back to a virtual potential. Ultimately, Deleuze argues, there can be no stopping the movement of actualization. Attempts will always be made to actualize the virtual potentiality of becoming, or to capture becoming through the inscription of particular forms of being. It is in relation to such attempts that we also find interesting ideas about how the virtual becomes an important part of contemporary security practices. For example, according to the primary aim and logic of contemporary counter-terrorism, it is the potentiality of an attack that must be responded to before it materializes, for example through the use of drones and 'kill lists'. What legitimates these and other exceptional security measures, for Presidents George W Bush as well as Barack Obama, is the necessity of acting directly on the future and abolishing the processes in which events unfold and become actualized. There is simply no time for actualization. The virtual potentiality of the event must be acted upon immediately, before it has made the journey into an actualized state of affairs. What is abolished in this process is a 'mediating present', which ties the past to the future in a linear direction. Instead of the present, the future has taken over as the main form of temporality; and instead of actuality, the virtual potentiality of the threat is the primary form of reality. Hence, as Massumi (2010: 55) puts it, there is:

a logical disjunction between the threat and the observable present. A logical gap opens in the present through which the reality of threat slips to rejoin its deferral to the future. Through the logical hatch of the double conditional, threat makes a runaround through the present back toward its self-causing futurity.

There is a time-slip in the logic of preemption, which enables a move from the more traditional way of responding to threats and dangers as they emerge and become actualized, to the practice of acting directly on the virtual potentiality of the threat: a practice that Massumi elsewhere refers to as 'potential politics' (2007). In potential politics, primacy must be given to preempting threats, not responding to them. This means acting directly on the virtual potentiality of the future event, or to actualize it without waiting for it. Actualization becomes, in this sense, a genuinely creative process 
that precedes and refigures the event. The future is folded into the present, and since the future has been reduced to nothing but its virtual potential there are no clear restrictions on what can and cannot be done in order to respond to it (see also Aradau and Van Munster, 2011; Adey and Anderson, 2012). As Donald Rumsfeld and others in the Bush administration realized, it is hard to argue against the reality of this virtual future; indeed the chances are very good that a primary concern with the future trumps any limits - 'legal' or 'democratic' - that may otherwise restrict certain actions to be taken in the present. To be able to play around with the indeterminacy of the virtual future is therefore much more important than a concern with the actualized present.

\section{Politicizing the relation between security and the virtual}

Thus far this article has delineated three different ways of conceptualizing the virtual: the virtual as a new reality (Baudrillard); the virtual as a potential reality (Agamben); and the reality of the virtual (Deleuze). So, how can these three approaches help us grasp the political stakes of the virtualization of security? Following the introduction, to answer this question we need to look more closely at how each approach closes down and/or opens up the possibility of resistance and political contestation. More precisely, we need to consider how the three approaches affect our understanding of the modern subject of security and especially its capacity to represent and refigure reality.

Starting with Baudrillard, it was noted earlier how the virtual can be linked to a new reality, which has left the 'old' reality principle based on actualization and representation. If we follow Baudrillard it is consequently within this virtual reality that security as well as insecurity must be analysed, not as two independent signifiers, or as two dialectically opposed sides, but as part of the same simulated 'hyperreality'. The dialectics of security/insecurity has disappeared, just like the dialectics of war and peace. 'Simulation is the master, and we only have a right to the retro, to the phantom, parodic rehabilitation of all lost referentials' (Baudrillard, 1994: 39). Only when simulation is the master does the desire for complete security become possible; only then can all ambivalence be removed; and only then does the world as such become 
'perfectly impossible' (Baudrillard and Noailles, 2007: 47). The old reality principle has been lost and there is no straightforward way of retrieving it, no way of knowing how to invent a language that can be used to bring back something that was lost before we even knew it had disappeared.

There can be no obvious escape from, or resistance to a virtual security order that has left us with no access to an actualized form of reality but only with a void or a desert of the real. The idealist challenge in security studies is, in this respect, no different from its realist target as both 'sides' ultimately seek to confirm that there is indeed a 'real' reality of security/insecurity. Instead of trying to hold on to this notion of reality, Baudrillard's concept of the virtual encourages us to focus on different techniques of simulating sovereignty and security (see Der Derian, 1993; Weber, 1995; Debrix and Barder, 2012). Such a focus takes us beyond the dichotomy of realism and idealism, and even beyond politics itself. We are, according to Baudrillard, beyond relations of power and force in the Foucauldian sense, hence beyond any 'real' clash of forces in the social field (Baudrillard, 2007: 31). For Baudrillard: 'The political stake is dead, only simulacra of conflicts and carefully circumscribed stakes remain' (Baudrillard, 1994: 34). It seems, thus, that 'all grounds for political activity have been removed' (Debrix, 2009: 58).

The disappearance of an actualized reality makes it hard, if not impossible, to study representational practices and the constitutive impact of language on the meaning of security/insecurity (cf. Campbell, 1998; Hansen, 2006). There is simply no meaning left to impose or inscribe. We are past meaning, left only with a void or an empty substance that 'no longer even knows the distinction between signifier and signified, nor between form and content' (Baudrillard, 1994: 64). It is therefore necessary to think beyond a world in which potential threats, fears and enemies are actualized by a sovereign subject who transforms them into something 'real'. Threats, fears and enemies are not waiting to be actualized by a sovereign subject. The only way they can be said to exist is as simulations and simulacra; that is, as part of a virtual reality that consists of copies of copies, which no longer bear any resemblance to an original or a model. It is precisely this reality, moreover, that makes the dream of 'total security' possible. Even if such a 
dream is impossible in an actualized sense, virtually the effects of total security can be simulated.

The desire for total security, which can never be actualized but virtually may constantly be aspired towards through increasing levels of simulation, is extremely dangerous. It is dangerous not least because if, indeed, the meaning and value of security are gradually transposed from an actual into a virtual realm, then it is highly unclear what strategies of resistance at all are available to contest whatever happens inside that realm. As something simulated, virtual reality lies beyond the capacity of subjects to represent and refigure the objects of security/insecurity. It is symptomatic, therefore, that the literature in security studies drawing on Baudrillard so far has only alluded to but not fully addressed the question of how to resist the violence of the virtual. While it is important to note that Baudrillard does, indeed, develop ideas about how to disrupt the reality produced by simulations (see Debrix, 2009: 64-65), there is undoubtedly a large portion of pessimism permeating Baudrillard's analysis of the virtual; a pessimism that is evident in many of his statements concerning the disappearance of politics in an age of virtual simulations.

If Baudrillard declares the political stakes of the virtual dead, Agamben raises the political stakes of the virtual. For Agamben, the virtual is deeply political as it highlights the potentiality of the biopolitical body to be reduced from the politically qualified life of bios to the simple fact of living and dying $(z o \bar{e})$. The virtual is political, moreover, because it signals an endless potential for sovereign power to actualize the sovereign ban. Hence, the most important political interaction in this biopolitical paradigm takes place between the potentiality of the biopolitical subject to be excluded, tortured and killed on the one hand, and the actualization of the sovereign ban on the other. In the zone of indistinction, where the potentiality and actuality to be killed and tortured are no longer separable, we find the extreme limits of sovereign power. It is here that the exception becomes the rule. In Homo Sacer Agamben illustrates these limits by pointing to the concentration camp as a space where decisions on who should live and who should die become totally arbitrary: a space where the actualization of the ban encounters the potentiality of abandonment in a completely random manner (see 
also Edkins, 2000). In State of Exception Agamben finds another paradigmatic example of this zone: the executive order signed by President Bush on 13 November 2001, authorizing indefinite detention and "trial by "military commissions" (not to be confused with the military tribunals provided for by the law of war) of noncitizens suspected of involvement in terrorist activities' (Agamben, 2005: 3).

In these extreme cases we see the creation of a zone of indistinction in which the violence that characterizes 'the state of virtual exception' is indistinguishable from the violence of 'the state of actual exception' (Agamben, 1998: 65, emphases added). The camp thus highlights a dangerous passage from the virtual potential of abandonment to the actualization of the ban. Here, the virtual is limited to the potentiality of being excluded and ultimately killed through sovereign exceptionalism. It is a potentiality that is actualized whenever the virtual state of exception becomes 'real'. Irrespective of its particular actualization this potentiality provides a necessary and underlying force that is vital to the continuous operation of sovereign power. If it were to suddenly disappear, sovereign power would have nothing to actualize, nothing to exclude or ban. At the heart of sovereign power, as well as of the 'biopolitics of security', there has to be a potentiality that makes life 'securable' in the first place (Dillon, 2003: 533). Potentiality and actuality are embedded in a biopolitics of security that is always ready to respond to the unpredictable emergence of new dangers and threats; always ready to make life expendable by actualizing the mark of potentiality inscribed in every political subject whose very existence depends on its capacity to be excluded and killed.

Agamben's concept of the virtual - pointing to how life is always potentially expendable - sheds light on the most violent aspects of contemporary security politics. At the same time, Agamben also develops ideas about how sovereign power breaks down and may ultimately be resisted. In brief, this has to do with the refusal to draw lines - the lines that determine who is included and excluded through the actualization of the sovereign ban. This refusal is, just like the ban, dependent on the potentiality of the virtual. However, in contrast to the sovereign ban, the refusal to draw lines does not accept the move towards actualization. In refusing the latter, potentiality is concerned only with 'potentiality itself' or with the potentiality not to pass into actuality. The 
potential to 'not-do' can, in this sense, also be thought of as something that renders actualization 'inoperative' (see Agamben, 2014).

Louise Amoore and Alexandra Hall (2013) use the example of 'clowns' participating in border-camp activism to highlight what this movement from the actual to the virtual in Agamben's biopolitical paradigm might entail. The clown, they suggest, haunts sovereign power by occupying the same ambiguous zone in-between the law and the exception, inside and outside. On the one hand, the clown's unique qualities - his illogical playfulness, childlike naivety, madness and foolery - place him outside of normal laws and duties, and make him someone who cannot quite be taken seriously. On the other hand, the clown has a long tradition of speaking truth to sovereign power and of reminding the sovereign of all the dangers lurking beyond his immediate grasp. The clown's position vis-à-vis the sovereign is, therefore, both playful and uneasy. Not only can he make the sovereign laugh; he reminds the sovereign of his own incompleteness and the many gaps underlying his apparatus of capture. In the context of border-camp activism, this unique position of the clown makes him a useful figure to imitate, as a way of resisting all those attempts at categorizing people as belonging on either side of a border. As Amoore and Hall (2013: 108) put it: 'The clown at the gates of the camp is a peculiar but fierce advocate of the life that teems within - he is a reminder of the excess, of that which will always slip away from the capacity to draw the line'.

The parable of the clown and his antics at the border demonstrates that the process of making sovereign power 'inoperative' is not to be confused with mere passivity, inactivity or inertia; it rather 'names an operation that deactivates' (Agamben, 2014: 69, emphasis added). Nor does the inoperative signal something 'negative'; its primary function is rather productive in the sense that it opens up to the creation of something new. Agamben (2014: 70) gives the example of poetry:

What is a poem, in fact, if not an operation taking place in language that consists in rendering inoperative, in deactivating its communicative and informative function, in order to open it to a new possible use? What the poem accomplishes for the potentiality of speaking, politics and philosophy 
must accomplish for the power of acting. Rendering inoperative the biological, economic, and social operations, they show what the human body can do, opening it to a new possible use.

If the biopolitical paradigm is conditioned by a dynamic relationship between the potentiality of being excluded and the actualization of the ban, the 'inoperative' highlights another potentiality: to render sovereign power incomplete and at the same time open up to something other and new, to a 'coming politics' (see Edkins, 2007; Prozorov, 2014: especially chapter 2). Another term for this other potentiality is formof-life: 'a life that can never be separated from its form, a life in which it is never possible to isolate something like a bare life'. This is a life 'in which the single ways, acts, and processes of living are never simply facts, but always and above all possibilities of life, always and above all potentiality [potenza]' (Agamben, 2014: 73, emphases in original).

Taking into account Agamben's notion of the inoperative we get closer to Deleuze's distinction between the reality of the virtual and the process of actualization (Prozorov, 2014: 55). We get closer, more precisely, to what Deleuze refers to as 'counteractualization': a process seeking to bring back the potentiality of the virtual that actualization sought to capture. 'Counter-actualization', writes Deleuze (2004b: 182), 'is to give to the truth of the event the only chance of not being confused with its inevitable actualization. ... To the extent that the pure event is each time imprisoned forever in its actualization, counter-actualization liberates it, always for other times.' In emphasising counter-actualization, what we find in Deleuze's philosophy is a double process that goes in two different directions at the same time: one that captures the virtual and one that liberates it. The latter process can thus be seen as a form of resistance to the ways in which the virtual event is actualized. It is a form of resistance that is based on an experimental practice of drawing new lines. 'Politics is active experimentation, since we do not know in advance which way a line is going to turn. Draw the line, says the accountant: but one can in fact draw it anywhere' (Deleuze and Parnet, 2006: 103, emphasis in original). Rather than refusing to draw lines, Deleuze points to the importance of drawing new lines, which can be used not only to challenge 
previous actualizations but to open up to other ways of actualizing the virtual movements of becoming. Regardless of how violently practices of security seek to capture the potentiality of becoming, or transform potentiality into particular forms of being, the former may always spring back to life, creating another possible world.

With Deleuze we end up in a virtual space that is highly creative, celebratory of the new and critical of all forms of capture that seek to transform becoming into being. It is a space that allows thought to experiment with the singularities of life; that resists common-sense claims and solutions; and that expresses a certain belief in the world. This is by far the most optimistic, life-affirming and, some would say, naïve concept of the virtual examined in this article. Deleuze even admits to this naivety in an interview, suggesting that his philosophy was probably the most naïve and innocent of his generation; that he was "the one who felt the least guilt about "doing philosophy", (Deleuze, 1995: 89). The underlying naivety of Deleuze's philosophy and of his concept of the virtual makes him an easy target of critique, especially for those who claim that there is hardly any space left in the contemporary world to draw 'new' lines. Deleuze's philosophy, we sometimes hear, might be relevant for thinking creatively about ontology but has nothing important to say about politics. I disagree. If contestation, resistance and the eruption of new forces are seen as primary conditions of politics, then any attempt to close down the virtual space of singularities and potentialities of life is inevitable a form of depoliticization. Conversely, attempts to open this space are expressions of politicization

\section{Conclusion}

Drawing on Baudrillard, Agamben and Deleuze, this article has delineated three different approaches to analysing the virtualization of security. The primary aim of doing so was to examine alternative accounts of reality, which go beyond the positivist/post-positivist divide in security studies and IR. According to this divide, reality is conceived either as an independently existing realm that can be known and represented as such, or as something that is produced by practices of interpretation and 
representation. In both cases, however, reality belongs to what may be referred to as an 'actualized' reality. The significance of the virtual is that it opens up to something other, which lies beyond the actual. At the same time, what this 'beyond' is, and what its relevance is to security studies are questions that lack pre-given answers; these answers depend, rather, on how the virtual is conceptualized.

Crucially, all three conceptualizations examined in this article take us beyond the dichotomy of virtuality/reality, according to which the virtual is contrasted to what is 'real', for example by trying to determine what constitutes a virtual as opposed to a real 'state' (see Rosecrance, 1999), or a virtual as opposed to a real 'war' (see Ignatieff, 2000). With Baudrillard, Agamben and Deleuze, we move beyond that dichotomy and find concepts of reality that, in different ways, are embedded in the virtual. For Baudrillard, the virtual relates to a simulated hyperreality, in which the capacity of modern subjects to actualize and represent objects has been lost; where the potentialities to radically alter the conditions of life have disappeared; and where the proliferation of screens has created a new post-political age. In Agamben's thought, the virtual can be used both for demonstrating how the potentialities of life are locked into a vicious relationship with the actualization of the sovereign ban, but also for thinking about how this relationship may be resisted by refusing to draw lines and thereby render sovereign power inoperative. Finally, Deleuze shows us how the virtual potentialities of life are both acted upon through a sovereign apparatus of capture, and exceeding the particular ways in which they are actualized through active experimentation and the drawing of new lines.

Since the virtual in all three cases is used in order to question and move beyond the dichotomy of reality/virtuality, any attempt to determine which one is most 'real', 'true' or 'accurate' is flawed. At the same time, it is crucial to take seriously their various political implications for analysing the virtualization of security. In this respect, it can be concluded that the main advantage of choosing Baudrillard's concept of the virtual is that it allows us to examine the violent implications of new technologies of simulation, which have created the impossible 'simulated' desire for total security. However, since the modern subject of security completely disappears in this simulated hyperreality, 
along with potentiality and actualization, there is no space left to refigure the objects of that reality. Baudrillard therefore has a lot less to offer when it comes to politicizing by way of resisting the virtualization of security. Agamben, on the other hand, combines the study of a violent biopolitics that relies on actualizing the virtual potentiality of the biopolitical subject to be tortured, excluded and killed, with a serious engagement with the potential to not-do; that is, the potential to not enter actuality, and render sovereign power inoperative by refusing to draw lines. Potentiality and actualization are thus still active and alive in Agamben's philosophy; they play an important political role, highlighting elements of capture as well as resistance in the virtualization of security.

However, it is Deleuze who pushes the political stakes of virtualization furthest. He does so by emphasising the potentialities of life itself: a life that belongs to active experimentation and the drawing of new lines. Irrespective of how totalising new technologies of simulation may seem, potentiality still has a role to play in Deleuze's philosophy. At the same time, there is also a politics in Deleuze's engagement with the virtual, which relates to the interaction between the virtual and the actual. In this sense, Deleuze's approach can also be seen as the most wide-ranging as he points as much to the violence of capture inherent in actualization, as to the potential of resistance in counter-actualization. Crucially, this approach does not necessarily rule out the insightful analyses by Baudrillard and Agamben. Ultimately, Deleuze's gesture is one of pluralism and openness to the multiplicity of lines running through our lives; lines of capture and lines of escape; old lines and new lines; actualized lines of being and pure lines of becoming; lines that constitute not just one politics, or two politics but many politics (Deleuze and Parnet, 2006: chapter 4).

\section{References}

Adey P and Anderson B (2012) Anticipating emergencies: Technologies of preparedness and the matter of security. Security Dialogue 43(2): 99-117. 
Agamben G (1998) Homo Sacer: Sovereign Power and Bare Life. Trans.

Heller-Roazen D. Stanford: Stanford University Press.

Agamben G (1999) Potentialities: Collected Essays in Philosophy. Trans.

Heller-Roazen D. Stanford: Stanford University Press.

Agamben G (2005) State of Exception. Trans. Attell K. Chicago: Chicago University Press.

Agamben G (2014) What is destituent power? Trans. Wakefield S. Environment and Planning D: Society and Space 32(1): 65-74.

Amoore L and Hall A (2013) The clown at the gates of the camp: Sovereignty, resistance and the figure of the fool. Security Dialogue 44(2): 93-110.

Aradau C and Van Munster R (2011) Politics of Catastrophe: Genealogies of the Unknown. London: Routledge.

Baudrillard J (1983) Simulations. Trans. Foss P, Patton P and Beitchman P. New York: Semiotext(e).

Baudrillard J (1994) Simulacra and Simulation. Trans. Glaser SF. Ann Arbor: University of Michigan Press.

Baudrillard J (1996) The Perfect Crime. Trans. Turner C. London: Verso.

Baudrillard J (2002) The Spirit of Terrorism and Other Essays. Trans. Turner C. London: Verso.

Baudrillard J (2007) Forget Foucault. Trans. Dufresne N. Los Angeles: Semiotext(e). 
Baudrillard J and Noailles EV (2007) Exiles from Dialogue. Trans. Turner C.

Cambridge: Polity.

Bogard W (1996) The Simulation of Surveillance: Hypercontrol in Telematic Societies. Cambridge: Cambridge University Press.

Booth K, Smith S and Zalewski M (eds) (1996) International Theory: Positivism and Beyond. Cambridge: Cambridge University Press.

Campbell D (1998) Writing Security: United States Foreign Policy and the Politics of Identity. 2nd edn. Manchester: Manchester University Press.

Colebrook C (2005) Philosophy and Post-structuralist Theory: From Kant to Deleuze. Edinburgh: Edinburgh University Press.

Debrix F (1999) Re-envisioning Peacekeeping: The United Nations and the Mobilization of Ideology. Minneapolis: University of Minnesota Press.

Debrix F (2009) Jean Baudrillard. In Edkins J and Vaughan-Williams N (eds) Critical Theorists and International Relations. London: Routledge, 54-65.

Debrix F and Barder AD (2012) Beyond Biopolitics: Theory, Violence and Horror in World Politics. London: Routledge.

Deleuze G (1995) Negotiations, 1972-1990. Trans. Joughin M. New York: Columbia University Press.

Deleuze G (2004a) Difference and Repetition. Trans. Patton P. London: Continuum.

Deleuze G (2004b) The Logic of Sense. Trans. Lester M with Stivale C. London: Continuum. 
Deleuze G and Guattari F (1994) What Is Philosophy? Trans. Burchell G and Tomlinson H. London: Verso.

Deleuze G and Parnet C (2006) Dialogues II. Trans. Tomlinson H and Habberjam B. London: Continuum.

Der Derian J (1990) The (s)pace of international relations: Simulation, surveillance, and speed. International Studies Quarterly 34(3): 295-310.

Der Derian J (1992) Antidiplomacy: Spies, Terror, Speed, and War. Cambridge, MA: Blackwell.

Der Derian J (1993) The value of security: Hobbes, Marx, Nietzsche, and Baudrillard. In Campbell D and Dillon M (eds) The Political Subject of Violence. Manchester: Manchester University Press, 94-113.

Der Derian J (2000) Virtuous war/virtual theory. Foreign Affairs 76(4): 771788.

Der Derian J (2001) Global events, national security, and virtual theory. Millennium: Journal of International Studies 30(3): 669-690.

Dillon M (2003) Virtual security: A life science of (dis)order. Millennium: Journal of International Studies 32(3): 531-558.

Dunne T, Kurki M and Smith S (eds) (2013) International Relations Theories: Discipline and Diversity. 3rd edn. Oxford: Oxford University Press.

Edkins J (2000) Sovereign power, zones of indistinction, and the camp. Alternatives: Global, Local, Political 25(1): 3-25. 
Edkins J (2007) Whatever politics. In Calarco M and DeCaroli S (eds) Giorgio Agamben: Sovereignty and Life. Stanford: Stanford University Press, 70-91.

Edkins J, Persram N and Pin-Fat V (eds) (1999) Sovereignty and Subjectivity. Boulder: Lynne Rienner.

Hansen L (2006) Security as Practice: Discourse Analysis and the Bosnian War. London: Routledge.

Hoy DC (2005) Critical Resistance: From Poststructuralism to Post-Critique. Cambridge, MA: MIT Press.

Huysmans J (2014) Security Unbound: Enacting Democratic Limits. London: Routledge.

Ignatieff M (2000) Virtual War: Kosovo and Beyond. London: Chatto \& Windus.

Lapid Y (1989) The third debate: On the prospects of international theory in a post-positivist era. International Studies Quarterly 33(3): 235-254.

Massumi B (2002) Parables for the Virtual: Movement, Affect, Sensation. Durham, NC: Duke University Press.

Massumi B (2007) Potential politics and the primacy of preemption. Theory \& Event 10(2): e-journal with no page numbers.

Massumi B (2010) The future birth of the affective fact: The political ontology of threat. In Gregg M and Seigworth GJ (eds) The Affective Theory Reader. Durham, NC: Duke University Press, 52-70. 
Mearsheimer JJ (1995) A realist reply. International Security 20(1): 82-93.

Prozorov S (2014) Agamben and Politics: A Critical Introduction. Edinburgh: Edinburgh University Press.

Rosecrance R (1999) The Rise of the Virtual State: Wealth and Power in the Coming Century. New York: Basic Books.

Shaviro S (2007) The 'wrenching duality' of aesthetics: Kant, Deleuze, and the 'theory of the sensible'. Available at:

http://www.shaviro.com/Othertexts/SPEP.pdf (accessed 11 November 2015).

Vaughan-Williams N (2010) The UK border security continuum: Virtual biopolitics and the simulation of the sovereign ban. Environment and Planning D: Society and Space 28(6): 1071-1083.

Walker RBJ (1997) The subject of security. In Krause K and Williams MC (eds) Critical Security Studies: Concepts and Cases. London: UCL Press, 6182.

Walt SM (1991) The renaissance of security studies. International Studies Quarterly 35(2): 211-240.

Weber C (1995) Simulating Sovereignty: Intervention, the State, and Symbolic Exchange. Cambridge: Cambridge University Press.

Williams C (2001) Contemporary French Philosophy: Modernity and the Persistence of the Subject. London: Athlone Press. 